\title{
BIDIKMISI: ANALISIS PELAKSANAAN PROGRAM BEASISWA PENDIDIKAN TINGGI
}

\author{
Rusi Rusmiati Aliyyah ${ }^{1}$, Sri Wahyuni Ulfah ${ }^{2}$, Endang Sri Budi Herawati ${ }^{3}$, \\ Reza Rachmadtullah ${ }^{4}$, Andes Safarandes Asmara ${ }^{5}$ \\ Universitas Djuanda Bogor ${ }^{1,2}$, Universitas Nahdlatul Ulama Cirebon ${ }^{3}$ \\ Universitas Universitas PGRI Adibuana ${ }^{4}$, Universitas Buana Perjuangan Kawarang ${ }^{5}$ \\ rusi.rusmiati@unida.ac.id ${ }^{1}$
}

\begin{abstract}
ABSTRAK
Penelitian bertujuan untuk mengetahui pelaksanaan program beasiswa BM. Penelitian ini menggunakan metode kualitatif studi kasus dengan menganalisis pelaksanaan program sesuai kriteria. Hasil penelitian menunjukan bahwa pelaksanaan program BM sesuai dengan perencanaan kriteria program. Struktur pengelola program berperan sesuai dengan tugas dan fungsinya. Mekanisme seleksi peserta program, pembinaan peserta program, monitoring dan evaluasi serta pelaporan pelaksanaan program berjalan dengan sangat baik. Simpulan, SDM pelaksana program sangat mendukung BM sehingga tugas dan tanggung jawab pengelola program terealisasi dengan sangat baik.
\end{abstract}

Kata Kunci: Beasiswa Bidikmisi, Pelaksanaan Program, Perguruan Tinggi

\begin{abstract}
The study aims to determine the implementation of the BM scholarship program. This study uses a qualitative case study method by analyzing program implementation according to criteria. The results showed that the implementation of the BM program was in accordance with the planning criteria for the program. The program manager structure has roles in accordance with its tasks and functions. The mechanism for selecting program participants, fostering program participants, monitoring and evaluation as well as reporting on program implementation went very well. In conclusion, the program implementing HR is very supportive of BM so that the duties and responsibilities of program managers are very well realized.
\end{abstract}

Keywords: Bidikmisi Scholarship, Program Implementation, Higher Education

\section{PENDAHULUAN}

Setiap warga Negara Republik Indonesia berhak mendapatkan pengajaran. Hak setiap warga negara tersebut telah dicantumkan dalam Pasal 31 (1) Undang-Undang Dasar 1945 dan Perubahannya bab XIII tentang pendidikan dan kebudayaan yang berbunyi: Setiap warga negara wajib mengikuti pendidikan dasar dan pemerintah wajib membiayainya ("Undang Undang Dasar Negara Republik Indonesia Tahun 1945," 
1945). Human rights education covers activities and practices to develop knowledge, skill, understanding, attitude and awareness which are necessary for promoting, preserving and advocating fundamental rights (Ozturk, 2017), including for students who have poor or poor economic ability (Benavot, 2016a). Berdasarkan hal tersebut, maka Pemerintah dan Pemerintah Daerah wajib memberikan layanan dan kemudahan, serta menjamin terselenggaranya pendidikan yang bermutu bagi setiap warga negara tanpa diskriminasi, dan masyarakat berkewajiban memberikan dukungan sumber daya dalam penyelenggaraan pendidikan.

Satu diantara factor rendahnya mutu pendidikan di Indonesia adalah karena kurangnya peningkatan pemerataan akses jenjang perguruan tinggi. Hal tersebut tercermin dari Angka Partisipasi Kasar (APK) yang baru mencapai 33.66\% dan angka tingkat melanjutkan ke perguruan tinggi masih rendah dibandingkan dengan negara berkembang pada umumnya. APK Perguruan Tinggi Jawa Barat pada tahun 2018 adalah 25.14, lebih rendah dari Banten dengan nilai 33.4, dan Aceh yang mencapai 43.86.

Tabel 1. Angka Partisipasi Kasar Perguruan Tinggi Menurut Provinsi

\begin{tabular}{|c|c|c|c|c|}
\hline \multirow[t]{2}{*}{ Provinsi } & \multicolumn{4}{|c|}{$\begin{array}{c}\text { Angka Partisipasi Kasar (APK) Perguruan } \\
\text { Tingga (PT) Menurut Provinsi }\end{array}$} \\
\hline & 2015 & 2016 & 2017 & 2018 \\
\hline Aceh & 41.67 & 42.06 & 45.73 & 43.86 \\
\hline Sumatera Utara & 25.89 & 28.93 & 30.71 & 31.11 \\
\hline Sumatera Barat & 38.51 & 40.54 & 43.53 & 44.19 \\
\hline Riau & 30 & 29.81 & 33.37 & 34.15 \\
\hline Jambi & 26.33 & 26.98 & 32.27 & 33.78 \\
\hline Sumatera Selatan & 18.6 & 21.64 & 23.77 & 26.23 \\
\hline Bengkulu & 36.53 & 41 & 41.52 & 38.31 \\
\hline Lampung & 12.46 & 16.05 & 18.84 & 21.32 \\
\hline Kep. Bangka Belitung & 11.13 & 14.48 & 15.01 & 13.2 \\
\hline Kep. Riau & 21.14 & 22.11 & 23.08 & 27.64 \\
\hline DKI Jakarta & 32.72 & 33.58 & 34.94 & 36.71 \\
\hline Jawa Barat & 21.31 & 24.59 & 25.5 & 25.14 \\
\hline Jawa Tengah & 19.28 & 19.69 & 21.88 & 21.96 \\
\hline DI Yogyakarta & 64.83 & 65.51 & 70.1 & 70.6 \\
\hline Jawa Timur & 22.14 & 28.13 & 30.23 & 29.99 \\
\hline Banten & 23.6 & 29.02 & 31.4 & 33.4 \\
\hline Bali & 32.06 & 31.61 & 35.81 & 36.4 \\
\hline Nusa Tenggara Barat & 26.3 & 25.89 & 28.09 & 29.75 \\
\hline Nusa Tenggara Timur & 24.51 & 26.92 & 29.21 & 30.14 \\
\hline Kalimantan Barat & 19.24 & 20.98 & 23.04 & 22.68 \\
\hline Kalimantan Tengah & 21.1 & 23.9 & 24.89 & 25.24 \\
\hline Kalimantan Selatan & 24.56 & 23.24 & 26.08 & 26.41 \\
\hline Kalimantan Timur & 28.44 & 31.6 & 35.58 & 35.64 \\
\hline Kalimantan Utara & 18.25 & 24.35 & 26.76 & 21.58 \\
\hline Sulawesi Utara & 27.68 & 31.32 & 31.74 & 35 \\
\hline Sulawesi Tengah & 31.56 & 35.3 & 39.22 & 40.61 \\
\hline Sulawesi Selatan & 40.44 & 40.75 & 43 & 41.23 \\
\hline Sulawesi Tenggara & 42.31 & 45.35 & 46.98 & 46.42 \\
\hline Gorontalo & 30.35 & 32.23 & 37.88 & 35.23 \\
\hline Sulawesi Barat & 25.51 & 27.54 & 29.72 & 28.9 \\
\hline
\end{tabular}




\begin{tabular}{lllll}
\hline Maluku & 44.46 & 46.38 & 47.39 & 48.42 \\
Maluku Utara & 33.72 & 40.87 & 45.01 & 42.68 \\
Papua Barat & 32.83 & 32.37 & 36.32 & 35.97 \\
Papua & 16.01 & 20.44 & 20.37 & 19.03 \\
Indonesia & 25.26 & 27.98 & 29.93 & 30.19 \\
\hline
\end{tabular}

$\overline{\text { Sumber: }}$ https://www.bps.go.id/

Selain itu peningkatan akses terhadap informasi dan sumber pendanaan juga relatif terbatas (Direktorat Jenderal Pembelajaran dan Kemahasiswaan Kementerian Riset Teknologi dan Pendidikan Tinggi, 2017). Oleh karena itu setiap peserta didik pada satuan pendidikan berhak mendapatkan bantuan biaya pendidikan bagi mereka yang memiliki potensi akademik baik dan tidak mampu secara ekonomi serta berhak mendapatkan beasiswa bagi mereka yang berprestasi.

Pangkalan Data Perguruan Tinggi (PDPT) Kemenristekdikti tahun 2019 memberikan data sebaran perguruan tinggi nengeri (PTN) dan perguruan tinggi swasta (PTS) di lingkungan Kemenristekdikti sebanyak 3.276 institusi dengan jumlah 122 untuk PTN dan 3.154 PTS. (https://forlap.ristekdikti.go.id).

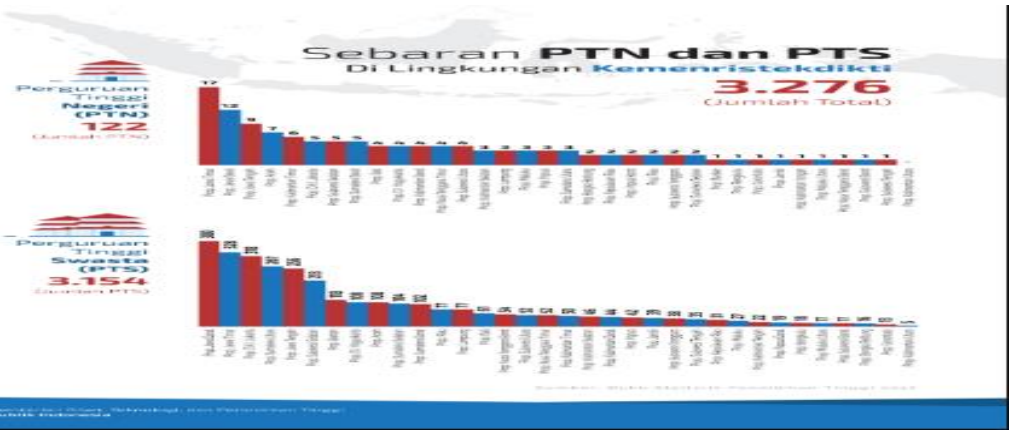

Gambar 1 Sebaran PTN dan PTS di Lingkungan Kemenristekdikti

Pada tahun 2015 Indonesia memiliki 24.057 jumlah prodi berdasarkan jenjang pendidikan dari Kemenristekdikti dan PTK dengan sebaran prodi terbanyak pada PTK ada pada Sekolah Tinggi sebanyak 2.741 dan 11.613 untuk prodi terbanyak pada Kemenristekditki ada pada Universitas. Sedangkan $60.67 \%$ mahasiswa berada pada jenjang pendidikan S1.

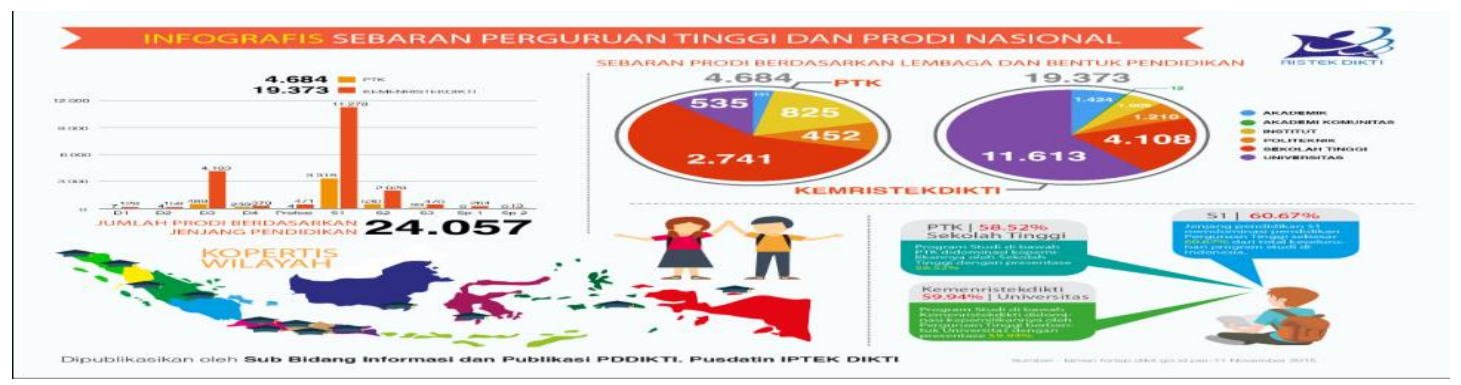

Gambar 2 Infografis Sebaran Perguruan Tinggi dan Prodi Nasional 
Direktorat Jenderal Pembelajaran dan Kemahasiswaan Kementerian Riset, Teknologi dan Pendidikan Tinggi memberikan kuota program beasiswa Bidikmisi sebanyak 259.760 pada semester gasal tahun anggaran 2016. Kouta tersebut tersebar kepada 121 perguruan tinggi negeri dan selebih nya diberikan kepada seluruh perguruan tinggi swasta yang berada dibawah naungan LLDIKTI wilayah I sampai dengan XIV. Sebaran kuota terbanyak program beasiswa Bidikmisi dari tahun 2013 sampai dengan 2016 pada semester gasal pertama diperolah oleh LLDIKTI wilayah X sebanyak 2.946, LLDIKTI wilayah IX sebanyak 2.858, LLDIKTI wilayah II sebanyak 2.299, LLDIKTI wilayah IV sebanyak 2.240, dan LLDIKTI wilayah XI sebanyak 2.272 (Kemristek Dikti, 2016a).

Berdasarkan total sebaran kuota penyaluran program beasiswa Bidikmisi pada masing-masing LLDIKTI tersebut, peneliti mendapatkan data bahwa pada tahun 2016, LLDIKTI X merupakan wilayah terbanyak pertama yang mendapatkan kuota program beasiswa Bidikmisi, yakni sebanyak 1,153. Selanjutnya kuota terbanyak kedua diperolah LLDIKTI IV yang mendapatkan kuota program beasiswa bidikimisi sebanyak 1,068, dan kuota terbanyak ketiga di berikan kepada LLDIKTI wilayah IX yakni sebanyak 1,060 (Kemristek Dikti, 2016b).

Jawa Barat merupakan salah satu target dalam pencapaian pemberantasan kemiskinan di Indonesia. Sebaran data jumlah penduduk miskin tersebut kemudian di laporkan oleh BPS melalui data persentase penduduk miskin menurut kabupaten dan kota di wilayah Jawa Barat. Berdasarkan data tersebut didapatkan informasi bahwa pada tahun 2017 jumlah penduduk miskin berada pada jumlah 3.774 atau $7.83 \%$. Meskipun jumlah tersebut sudah menurun dari tahun ke tahun, namun pemerintah masih harus menekan angka kemiskinan tersebut.

Tabel 2 Garis Kemiskinan dan Penduduk Miskin di Provinsi Jawa Barat, 2011-2017

\begin{tabular}{|c|c|c|c|} 
Tahun & Garis Kemiskinan & \multicolumn{2}{|c|}{ Penduduk Miskin } \\
\cline { 3 - 4 } & (rupiah) & Jumlah (Juta Jiwa) & Persentase \\
2011 & 226097 & 4,650 & 10,57 \\
2012 & 242104 & 4,421 & 9,89 \\
2013 & 276825 & 4,382 & 9,61 \\
2014 & 291474 & 4,238 & 9,18 \\
2015 & 318602 & 4,485 & 9,57 \\
2016 & 332119 & 4,168 & 8,77 \\
2017 & 354679 & 3,774 & 7,83
\end{tabular}

Sumber: https://jabar.bps.go.id/

Padatnya masyarakat di wilayah Jawa Barat juga berbanding lurus dengan banyaknya lulusan pada sekolah menengah, baik SMA, SMK ataupun MA di wilayah Jawa Barat yang memperoleh nilai prestasi akademik yang baik dan sebagian besar masyarakat Jawa Barat melanjutkan program studi sarjana nya ke perguruan tinggi swasta. Hal ini yang menjadikan salah satu faktor banyak nya jumlah dan sebaran perguruan tinggi swasta di Jawa Barat di bandingkan dengan wilayah lain di Indonesia. Jawa Barat merupakan kawasan pertama yang mempunyai perguruan tinggi terbanyak pada tahun 2019 dengan jumlah perguruan tinggi swasta sebanyak 367 dan jumlah mahasiswa sebesar 399.428 orang (http://forlap.dikti.go.id,). 
Jawa Barat merupakan binaan dari LLDIKTI wilayah IV. Jumlah perguruan tinggi yang ada di LLDIKTI wilayah IV pada tahun 2019 terdiri dari 87 akademi, 27 politeknik, 192 sekolah tinggi, 6 institut dan 49 universitas, 3 akademi komunitas. Adapun grafik jumlah perguruan tinggi tersebut adalah sebagaimana gambar 3 berikut: (http://forlap.dikti.go.id,).

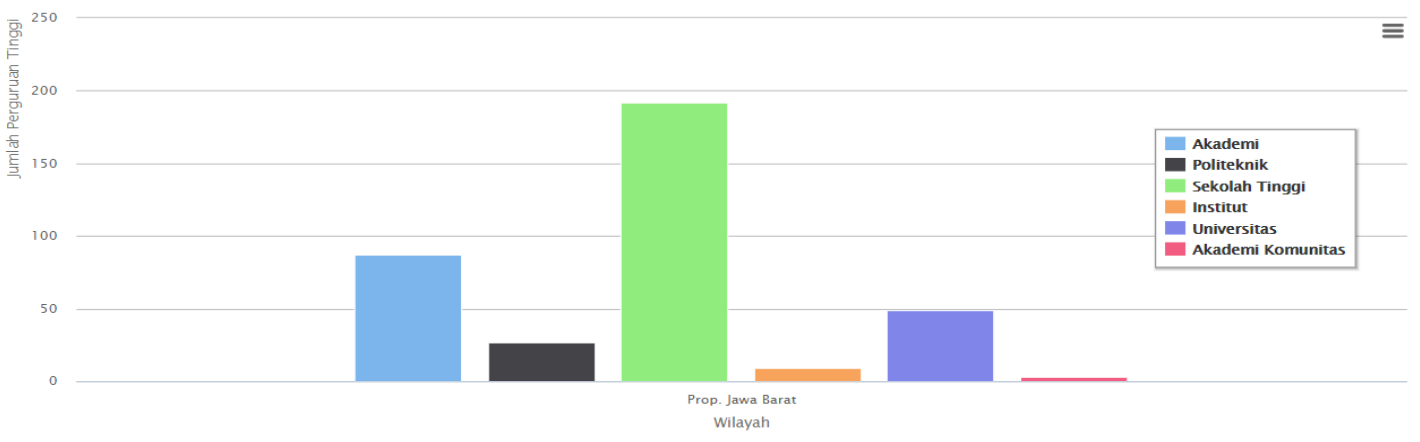

Gambar 3 Jumlah Perguruan Tinggi Swasta di LLDIKTI Wilayah IV

Sumber: Pangkalan Data Pendidikan Tinggi Kementerian Riset, Teknologi dan Pendidikan Tinggi.

LLDIKTI IV mendapatkan program beasiswa Bidikmisi pertama kali dari Kemendikbud mulai pada tahun 2013. Dengan demikian, sampai pada tahun 2017, LLDIKTI wilayah IV sudah memperoleh program beasiswa tersebut selama 4 tahun ajaran. Dari data laporan pelaksanaan program beasiswa Bidikmisi semester genap tahun akademik 2013/2014 Kementerian Pendidikan dan Kebudayaan RI, diperoleh data sebanyak 14 perguran tinggi swasta dibawah naungan LLDIKTI wilayah 4 memperoleh bantuan program beasiswa Bidikmisi (Kementerian Pendidikan dan Kebudayaan, 2014). Informasi senada juga peneliti dapatkan dari hasil wawancara dengan koordinator bagian beasiswa Bidikmisi pada LLDIKTI wilayah IV yang menyatakan bahwa dari total 108 perguruan tinggi yang mendapatkan bantuan program beasiswa Bidikmisi sampai dengan tahun 2016 ini, hanya 14 perguruan tinggi yang mendapatkan program beasiswa Bidikmisi mulai dari tahun 2013 dan sudah mencapai 4 tahun ajaran.

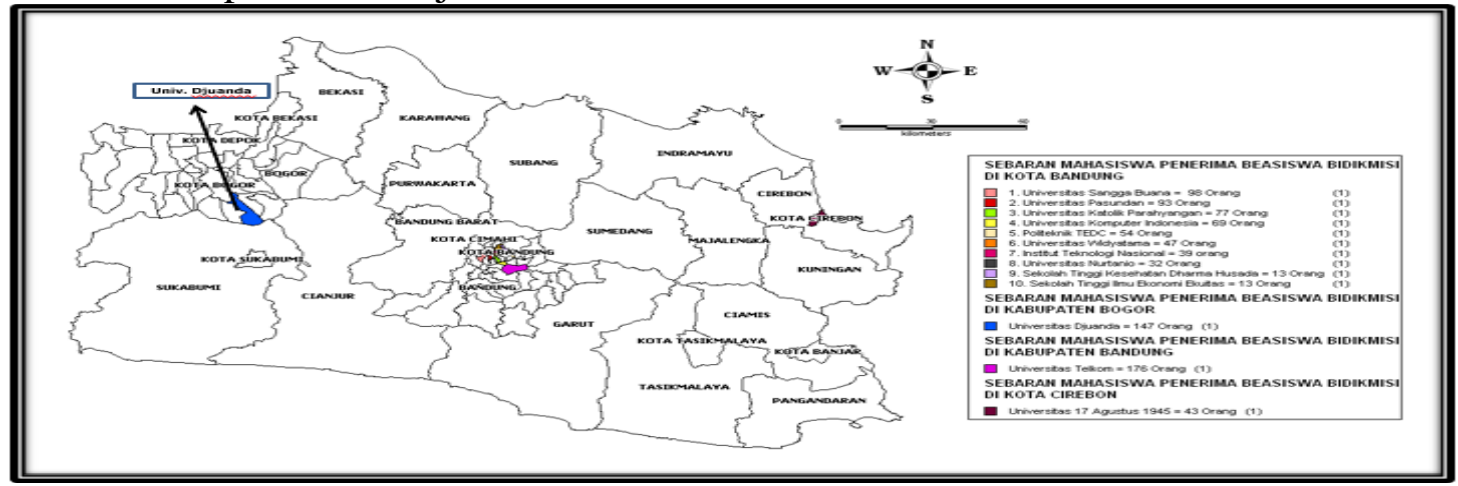

Gambar 4 Sebaran perguruan tinggi yang mendapatkan program beasiswa Bidikmisi mulai tahun 2013

Sumber: Dokumentasi LLDIKTI Wilayah IV 
Universitas Djuanda (UNIDA) Bogor merupakan satu diantara perguruan tinggi swasta yang mendapatkan bantuan program beasiswa Bidikmisi mulai tahun 2013 dengan jumlah mahasiswa penerima program kedua terbanyak di LLDIKTI wilayah IV setelah Univeritas Telkom Bandung. Berdasarkan data tersebut peneliti merasa penting untuk melakukan penelitian di UNIDA Bogor. Hal tersebut menjadi pilihan peneliti, mengingat biaya kuliah di perguruan tinggi tersebut lebih besar dari bantuan biaya pendidikan beasiswa Bidikmisi yang diberikan oleh Kemenristekdikti. Pada tahun ajaran 2017, biaya masuk UNIDA Bogor rata-rata per prodi nya sebesar Rp 3.679.000,- dan biaya SPS atau gedung sebesar Rp. 7.000.000,-. Sementara alokasi pemberian dana pendidikan beasiswa Bidikmisi dari Kemenristekdikti hanya sebesar Rp 2.400.000,-/semester dan Rp 650.000,-/bulan untuk biaya hidup mahasiswa/orang. Berdasarkan hal tersebut, maka peneliti tertarik untuk melakukan penelitian evaluasi program beasiswa Bidikmisi di UNIDA Bogor.

Jumlah mahasiswa penerima program beasiswa Bidikmisi di UNIDA Bogor tersebar dalam 6 (enam) fakultas (Biro Akademik Administrasi dan Kemahasiswaan UNIDA, 2016). Yakni Fakultas Pertanian, Fakultas Ilmu Pangan Halal, Fakultas Ekonomi, Fakultas Hukum, Fakultas Ilmu Sosial danIlmu Politik, dan Fakultas Keguruan dan Ilmu Pendidikan. Adapun sebaran jumlah mahasiswa penerima program beasiswa Bidikmisi tersebut dapat dilihat pada tabel 4 sebagaimana berikut:

Tabel 3 Jumlah dan Sebaran Mahasiswa Penerima Program

Beasiswa Bidikmisi di UNIDA Bogor

\begin{tabular}{llcccccc}
\hline \multirow{2}{*}{ No } & & \multicolumn{5}{c}{ Angkatan } & Jumlah \\
\cline { 3 - 6 } & & 2013 & 2014 & 2015 & 2016 & 2017 & \\
\hline 1 & Fakultas Pertanian, & 21 & 7 & 5 & 9 & 1 & 42 \\
2 & Fakultas Ilmu Pangan Halal, & 7 & 5 & 7 & 11 & 5 & 30 \\
3 & Fakultas Ekonomi, & 5 & 6 & 7 & 8 & 9 & 26 \\
4 & Fakultas Hukum, & 2 & 3 & 4 & 6 & 2 & 15 \\
5 & Fakultas Ilmu Sosial dan Ilmu Politik, & 8 & 4 & 4 & 1 & 5 & 17 \\
6 & Fakultas Keguruan dan Ilmu Pendidikan & 6 & - & 6 & 5 & 3 & 17 \\
\hline & Jumlah & 49 & 25 & 33 & 40 & 25 & 172 \\
\hline
\end{tabular}

Sumber : Dokumen BAAK Universitas Djuanda Bogor

Penelitian dilakukan untuk mengetahui analisis pelaksanaan program beasiswa Bidikmisi pada Universitas Djuanda Bogor dengan mengambil data penelitian tahun 2013 sampai dengan 2017.

\section{METODE PENELITIAN}

Penelitian dilaksanakan di UNIDA Bogor yang merupakan salah satu perguruan tinggi di LLDIKTI wilayah IV yang telah menerima program beasiswa Bidikmisi untuk mahasiswa yang tidak mampu selama 6 tahun dari Direktorat Jenderal Pembelajaran dan Kemahasiswaan Kementerian Riset, Teknologi dan Pendidikan Tinggi. Penelitian dilakukan kepada 6 (enam) fakultas yaitu : Fakultas Pertanian, Fakultas Ilmu Pangan Halal, Fakultas Ekonomi, Fakultas Hukum, Fakultas Ilmu 
Sosial dan Ilmu Politik, Fakultas Keguruan dan Ilmu Pendidikan. Waktu pelaksanaan penelitian dilaksanakan pada bulan Juli 2017 sampai dengan bulan Desember 2018.

Penelitian ini menggunakan pendekatan kualitatif. Penelitian kualitatif diartikan sebagai "Qualitative research is the collection, analysis and interpretation of comprehensive narrative and visual data to gain insights into a particular phenomeon of interest", dijabarkan bahwa penelitian kualitatif adalah mengumpulkan, menganalisis dan menginterpretasikan data visual dan naratif untuk mendalami suatu fenomena.

Aspek yang dianalisis dalam penelitian ini adalah pelaksanaan program beasiswa Bidikimisi yang terdiri dari struktur pengelola program, daya dukung administrasi, daya dukung SDM, daya dukung sarana prasarana, serta tugas dan tanggung jawab pengelola program beasiswa Bidikmisi. Berikut adalah tabel kriteria yang digunakan dalam analisis program beasiswa Bidikmisi di Universitas Djuanda Bogor.

Tabel 4. Kriteria Analisis Program Beasiswa Bidikmisi di Universitas Djuanda Bogor

\begin{tabular}{|c|c|c|c|}
\hline Analisis & $\begin{array}{l}\text { Aspek yang } \\
\text { di analisis }\end{array}$ & Kriteria Analisis & Sub Kriteria Analisis \\
\hline \multirow[t]{8}{*}{$\begin{array}{l}\text { Pelaksaan } \\
\text { Program }\end{array}$} & $\begin{array}{l}\text { Struktur pengelola } \\
\text { program }\end{array}$ & $\begin{array}{lc}\text { Struktur } & \text { organisasi } \\
\text { pengelola/pelaksana } \\
\text { program } \quad \text { beasiswa } \\
\text { Bidikmisi } & \\
\end{array}$ & $\begin{array}{lrr}\text { Adanya } & \text { struktur } & \text { organisasi } \\
\text { pengelola/pelaksana } & \text { program } \\
\text { beasiswa Bidikmisi } & \text { di } & \text { UNIDA } \\
\text { Bogor sesuai dengan perencanaan }\end{array}$ \\
\hline & $\begin{array}{l}\text { Daya dukung } \\
\text { administrasi }\end{array}$ & $\begin{array}{l}\text { Mekanisme seleksi peserta } \\
\text { program }\end{array}$ & $\begin{array}{l}\text { Terdapat } 5 \text { ketentuan administrasi } \\
\text { dalam mekanisme seleksi }\end{array}$ \\
\hline & & $\begin{array}{l}\text { Mekanisme pembinaan } \\
\text { peserta program }\end{array}$ & Memiliki mekanisme pembinaan \\
\hline & & $\begin{array}{l}\text { Mekanisme monitoring } \\
\text { dan supervise program }\end{array}$ & $\begin{array}{l}\text { Memiliki mekanisme monitoring dan } \\
\text { supervise }\end{array}$ \\
\hline & & $\begin{array}{lr}\begin{array}{l}\text { Mekanisme } \\
\text { pelaksanaan }\end{array} & \text { pelaporan } \\
\text { peasiswa } & \\
\end{array}$ & 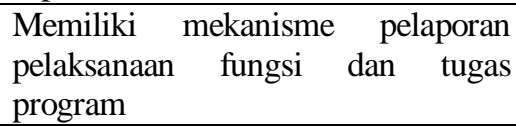 \\
\hline & Daya dukung SDM & $\begin{array}{l}\text { Daya dukung } \text { SDM } \\
\text { pelaksana program } \\
\text { beasiswa Bidikmisi }\end{array}$ & $\begin{array}{llll}\text { Adanya } & \text { realisasi daya } & \text { dukung } \\
\text { SDM } & & & \end{array}$ \\
\hline & $\begin{array}{l}\text { Daya dukung sarana } \\
\text { prasarana }\end{array}$ & $\begin{array}{ll}\text { Sarana } & \text { prasarana } \\
\text { program } & \text { beasiswa } \\
\text { Bidikmisi } & \\
\end{array}$ & $\begin{array}{l}\text { Adanya realisasi daya dukung } \\
\text { sarana prasarana program }\end{array}$ \\
\hline & $\begin{array}{l}\text { Tugas dan tanggung } \\
\text { jawab pengelola } \\
\text { program beasiswa } \\
\text { Bidikmisi }\end{array}$ & $\begin{array}{lr}\text { Pelaksanaan } & \text { tugas dan } \\
\text { tanggung } & \text { jawab } \\
\text { pengelola } & \text { program } \\
\text { beasiswa Bidikmisi }\end{array}$ & $\begin{array}{l}\text { Pelaksanaan tugas dan tanggung } \\
\text { jawab pengelola program beasiswa } \\
\text { Bidikmisi sesuai perencaaan }\end{array}$ \\
\hline
\end{tabular}

Pengumpulan data dilakukan melalui observasi, wawancara, dokumentasi, dan kuesioner. Posedur analisis data yang digunakan dalam penelitian ini sebagaimana dikemukakan Miles and Huberman, yakni terdiri atas tiga alur kegiatan yang terjadi secara bersamaan, yaitu reduksi data, penyajian data dan verifikasi/penarikan kesimpulan. Sedangkan teknik pemeriksaan keabsahan (trustworthiness) data dilakukan untuk menghindari kesalahan data yang akan dianalisis. Keabsahan data merujuk pada 4 
kriteria yakni derajat kepercayaan (credibility), keteralihan (transferability), kebergantungan (dependability), dan kepastian (comfirmability).

\section{HASIL PENELITIAN}

\section{Struktur Pengelola Program Beasiswa Bidikmisi}

Struktur pengelola program beasiswa Bidikmisi UNIDA melibatkan sejumlah sumber daya manusia. Pimpinan perguruan tinggi mulai dari rector, wakil rector, dan kepala biro menjadi bagian dalam pengelolaan program.

Pengelola program Bidikmisi di UNIDA sangat banyak. Hampir semua stakeholder dilibatkan dalam mengelola, mulai dari pembina, yayasan, rektor, wakil rektor, kepala biro, dekan, wakil dekan, prodi dan pembimbing akademik mahasiswa. Semua diberikan tanggung jawab dalam melakukan rekrutmen dan pembinaan Bidikmisi (A1.8).

Tabel 5 Struktur Pengelola Program Beasiswa Bidikmisi

\begin{tabular}{llll}
\hline NO & Obyek Observasi & \multicolumn{2}{c}{ Keadaan } \\
\cline { 3 - 4 } & & \multicolumn{1}{c}{ Berfungsi } & $\begin{array}{c}\text { Tidak } \\
\text { Berfungsi }\end{array}$ \\
\hline 1 & Penanggung Jawab & \multicolumn{1}{c}{ Rektor } & $\checkmark$ \\
\hline 2 & Pelaksana & Wakil Rektor Bidang Akademik & $\checkmark$ \\
\cline { 2 - 4 } & Wakil Rektor Bidang Kemahasiswaan & $\checkmark$ \\
\cline { 2 - 3 } & Kepala Biro Bidang Akademik & $\checkmark$ \\
\cline { 2 - 3 } & Kepala Biro Bidang Kemahasiswaan & $\checkmark$ \\
\cline { 2 - 3 } & Kepala Biro Bidang Keuangan & $\checkmark$ \\
\cline { 2 - 3 } & Kepala Biro Lembaga Pengkajian dan & $\checkmark$ \\
& Pengembagan Tahid (LP2T) & \\
\hline
\end{tabular}

Sumber: Catatan Observasi dan Wawancara

Unsur-unsur pengelola program berjalan sesuai dengan tugas dan fungsinya masing-masing. Penanggung jawab di jabat oleh rector, sedangkan pelaksana program terdiri dari wakil rector bidang akademik, wakil rector bidang kemahasiswaan, kepala biro bidang akademik, kepala biro bidang kemahasiswaan, kepala biro bidang keuangan, kepala biro lembaga pengkajian dan pengembangan tauhid (LP2T).

Tabel 6 Perbandingan Pengelola Program antara Design dengan Installasi

\begin{tabular}{lllc}
\hline \multirow{2}{*}{1} & \multicolumn{2}{c}{ Unsur Pengelola } \\
\cline { 2 - 3 } 2 & \multicolumn{1}{c}{ Desain Program } & Kondisi Obyektif \\
\cline { 2 - 3 } & $\begin{array}{l}\text { Penanggung } \\
\text { Jawab }\end{array}$ & \multicolumn{1}{c}{ Rektor } & Ada \\
\cline { 2 - 3 } & Pelaksana & Wakil Rektor Bidang Akademik & Ada \\
\cline { 2 - 3 } & Wakil Rektor Bidang Kemahasiswaan & Ada \\
\cline { 2 - 3 } & Kepala Biro Bidang Akademik & Ada \\
\cline { 2 - 3 } & Kepala Biro Bidang Kemahasiswaan & Ada \\
\cline { 2 - 3 } & Kepala Biro Bidang Keuangan & Ada \\
\cline { 2 - 3 } & Kepala Biro Lembaga Pengkajian dan & Ada \\
\hline
\end{tabular}




\begin{tabular}{|c|c|c|}
\hline \multirow[t]{4}{*}{$\mathrm{NO}$} & \multicolumn{2}{|c|}{ Unsur Pengelola } \\
\hline & Desain Program & Kondisi Obyektif \\
\hline & \multicolumn{2}{|l|}{ Pengembagan Tahid (LP2T) } \\
\hline & Tidak Ada & Kepala Biro IT \\
\hline
\end{tabular}

Sumber: Catatan Observasi dan Wawancara

Struktur pengelola program beasiswa Bidikmisi UNIDA melibatkan sejumlah sumber daya manusia, mulai dari rektor, wakil rektor, dan kepala biro menjadi bagian dalam pengelolaan program dengan tugas dan tanggung jawab pengelola program masing-masing. Semua pengelola program beasiswa Bidikmisi di UNIDA berjalan sesuai dengan tugas dan fungsinya masing-masing.

\section{Daya Dukung Administrasi}

Sistem administrasi program beasiswa Bidikmisi mencakup 4 indikator, yaitu mekanisme seleksi peserta, pembinaan peserta, monitoring dan evaluasi serta pelaporan pelaksanaan program.

\section{Mekanisme Seleksi Peserta Program}

Mekanisme seleksi peserta program adalah proses yang dilakukan sejak pengumuman penerimaan calon peserta sampai dengan pengumuman penetapan yang diterima program. Terdapat 5 ketentuan administrasi dalam mekanisme seleksi, yakni diseminasi informasi program, persyaratan administrasi peserta, seleksi peserta, penetapan calon penerima program dan tim seleksi program dengan 32 indikator.

Seleksi peserta program, mencakup TPA, Bahasa Inggris, Wawancara, dan Psikotest. Penetapan calon penerima Bidikmisi yang terdiri dari SK rector tentang penetapan penerima beasiswa dan dokumen sosialisasi peserta yang diterima. Tim seleksi peserta program yang terdiri dari panitia pengelola program.

Tabel 7 Kondisi Obyektif Mekanisme Seleksi Peserta Program Beasiswa Bidikmisi

\begin{tabular}{lllc}
\hline & & & \multicolumn{2}{c}{ Obyek Observasi } & Keaan \\
\cline { 3 - 3 } NO & Bentuk administrasi & & $\begin{array}{c}\text { Tidak } \\
\text { Ada }\end{array}$ \\
\hline 1 & Diseminasi informasi & Pengumuman penerimaan program & $\checkmark$ \\
2 & & Jadwal kegiatan penerimaan program & $\checkmark$ \\
\hline 3 & Persyaratan program & Formulir pendaftaran & $\checkmark$ \\
4 & & Raport & $\checkmark$ \\
5 & & Piagam Prestasi & $\checkmark$ \\
6 & Kartu Keluarga & $\checkmark$ \\
7 & & Surat Keterangan Tidak Mampu & $\checkmark$ \\
8 & & Kartu Tanda Siswa & $\checkmark$ \\
9 & & Photo Rumah & $\checkmark$ \\
10 & & Photo Bersama Keluarga & $\checkmark$ \\
11 & & Photo Pribadi & $\checkmark$ \\
12 & & Surat Rekomendasi dari Sekolah & $\checkmark$ \\
13 & & Photo Copy Rekening Listrik & $\checkmark$ \\
14 & & Surat Penghasilan Orang Tua & $\checkmark$ \\
\hline 15 & Seleksi Peserta Program & Test Potensi Akademik & $\checkmark$
\end{tabular}




\begin{tabular}{|c|c|c|c|c|}
\hline \multirow[b]{2}{*}{ NO } & \multirow[b]{2}{*}{ Bentuk administrasi } & \multirow[b]{2}{*}{ Obyek Observasi } & \multicolumn{2}{|c|}{ Keadaan } \\
\hline & & & Ada & $\begin{array}{c}\text { Tidak } \\
\text { Ada }\end{array}$ \\
\hline 16 & & Materi Test Potensi Akademik & $\checkmark$ & \\
\hline 17 & & Test Bahasa Inggris & $\checkmark$ & \\
\hline 18 & & Materi Test Bahasa Inggris & $\checkmark$ & \\
\hline 19 & & Wawancara & $\checkmark$ & \\
\hline 20 & & Pedoman Wawancara & $\checkmark$ & \\
\hline 21 & & Psikotest & $\checkmark$ & \\
\hline 22 & & Dokumen Hasil Psikotest & $\checkmark$ & \\
\hline 23 & Penetapan calon penerima & SK Penetapan Pemberian Beasiswa Bidikmisi & $\checkmark$ & \\
\hline 24 & program & Rapat penetapan peserta program yang diterima & $\checkmark$ & \\
\hline 25 & & Pengumuman Peserta yang Diterima & $\checkmark$ & \\
\hline 26 & Tim Seleksi & SK Panitia Seleksi & $\checkmark$ & \\
\hline
\end{tabular}

Sumber: Catatan hasil observasi dan wawancara biro PMB, LP2T dan Kemahasiswaan

\section{Mekanisme Pembinaan Peserta Program}

Mekanisme pembinaan peserta program adalah ketentuan yang berkenaan dengan penegakan kedisiplinan peserta program beasiswa Bidikmisi. Ketentuan penegakan disiplin mencakup 3 unsur yaitu tata tertib peserta program, proses penegakan tata tertib serta kegiatan kokurikuler dan ekstrakurikuler peserta program.

Mahasiswa Bidikmisi di bina oleh stakeholders UNIDA. Mulai dari dekan, wakil dekan, prodi, dosen pembimbing akademik, kepala asrama bahkan yayasan dan pembina langsung ikut melakukan pembinaan kepada mahasiswa Bidikmisi (A1.10).

Tabel 8 Kondisi Obyektif Mekanisme Pembinaan Peserta Program

\begin{tabular}{llcc}
\hline NO & \multicolumn{1}{c}{ Obyek Observasi } & \multicolumn{2}{c}{ Keadaan } \\
& & $\checkmark$ & \\
\hline 1 & Tata Tertib Mahasiswa UNIDA & $\checkmark$ & \\
2 & Ketentuan Etika Mahasiswa UNIDA & $\checkmark$ & \\
3 & Daftar Kewajiban Peserta Program & $\checkmark$ & \\
4 & Ketentuan Target Peserta Program & $\checkmark$ & \\
5 & Sistem Penghargaan dan Hukuman & $\checkmark$ & \\
6 & Kegiataan kokurikuler mahasiswa & $\checkmark$ & \\
7 & Kegiatan ekstrakurikuler mahasiswa & $\checkmark$ & \\
8 & Kegiatan UKM & $\checkmark$ & \\
9 & Kegiatan Asrama Mahasiswa & $\checkmark$ & \\
10 & Penanggung Jawab & \multicolumn{2}{c}{} \\
\hline
\end{tabular}

Sumber: Dokumen Biro Kemahasiswaan UNIDA

\section{Mekanisme Monitoring dan Supervisi Program}

Tabel 9 Mekanisme Monitoring dan Supervisi Program Beasiswa Bidikmisi

\begin{tabular}{|c|c|c|}
\hline & & Keadaan \\
\hline No & Obyek Observasi & Ada Tidak Ada \\
\hline \multicolumn{3}{|c|}{ Alokasi dan Pencairan Dana } \\
\hline 1 & Dokumen bebas biaya pendaftaran & $\checkmark$ \\
\hline 2 & $\begin{array}{l}\text { SK rektor yang menetapkan bahwa adanya besaran bantuan biaya } \\
\text { hidup dan biaya pendidikan }\end{array}$ & $\checkmark$ \\
\hline
\end{tabular}




\begin{tabular}{|c|c|c|}
\hline & & Keadaan \\
\hline No & Obyek Observasi & Ada Tidak Ada \\
\hline \multicolumn{3}{|c|}{ Alokasi dan Pencairan Dana } \\
\hline 3 & $\begin{array}{l}\text { Dokumen penggantian biaya transport bagi mahasiswa yang berasal } \\
\text { dari luar kabupaten/kotamadya }\end{array}$ & $\checkmark$ \\
\hline 4 & Buku kas dana masuk per semester & $\checkmark$ \\
\hline \multicolumn{3}{|c|}{ Penyaluran dan Penggunaan Dana } \\
\hline 5 & Rekening perguruan tinggi & $\checkmark$ \\
\hline 6 & Rekening mahasiswa peserta program & $\checkmark$ \\
\hline 7 & $\begin{array}{l}\text { SK kekurangan bantuan biaya penyelenggaraan Bidikmisi di UNIDA } \\
\text { yang digantikan dengan peroleh dari sumber dana lain }\end{array}$ & $\checkmark$ \\
\hline 8 & Prosedur penyaluran dana program beasiswa Bidikmisi & $\checkmark$ \\
\hline \multicolumn{3}{|c|}{ Pelayanan dan Pembinaan Mahasiswa } \\
\hline 9 & $\begin{array}{l}\text { Kegiatan ko dan ekstra kurikuler mahasiswa penerima beasiswa } \\
\text { Bidikmisi }\end{array}$ & $\checkmark$ \\
\hline 10 & $\begin{array}{l}\text { Surat perjanjian yang dibuat antara UNIDA dan mahasiswa penerima } \\
\text { Bidikmisi yang memuat tentang hak dan kewajiban }\end{array}$ & $\checkmark$ \\
\hline 11 & Dokumen kepatuhan mahasiswa terhadap tata tertib kampus & $\checkmark$ \\
\hline \multicolumn{3}{|c|}{ Tim Pelaksana Monitoring dan Supervisi } \\
\hline 12 & Monitoring oleh DIKTI yang meninjau laporan program & $\checkmark$ \\
\hline 13 & Monitoring yang dilakukan oleh PT & $\checkmark$ \\
\hline 14 & $\begin{array}{l}\text { Team pelaksana monitoring dan supervise yang dibentuk untuk } \\
\text { program beasiswa Bidikmisi di UNIDA Bogor }\end{array}$ & $\checkmark$ \\
\hline 15 & IPS peserta program & $\checkmark$ \\
\hline 16 & IPK peserta program & $\checkmark$ \\
\hline
\end{tabular}

Sumber: Dokumen, Wawancara dan Observasi

Mekanisme monitoring dan supervisi adalah bentuk kegiatan pemantauan, pembinaan dan penyelesaian masalah terhadap pelaksanaan program beasiswa Bidikmisi. Secara umum tujuan kegiatan ini adalah untuk meyakinkan bahwa seleksi, pembinaan dan penyaluran dana telah dilakukan dengan baik sesuai dengan pedoman Bidikmisi dan telah memenuhi aspek program yang berprinsip pada tepat sasaran, tepat jumlah, dan tepat waktu.

\section{Mekanisme Pelaporan Pelaksanaan Program Beasiswa Bidikmisi}

Mekanisme pelaporan pelaksanaan program adalah proses pertanggung jawaban pelaksanaan fungsi dan tugas program. Dalam mekanisme pelaporan program disampaikan secara administratif pelaksanaan fungsi dan tugasnya.

Perguruan Tinggi diberikan account oleh DIKTI sebagai alat untuk melakukan pemantauan dan laporan perkembangan mahasiswa Bidikmisi. Selanjutnya setiap semester kami selalu diminta laporan IPK yang harus diinput ke dalam sistem yang disediakan tersebut (A1.8).

Tabel 10 Kondisi Obyektif Mekanisme Pelaporan Program

\begin{tabular}{clc}
\hline NO & \multicolumn{1}{c}{ Obyek Observasi } & \multicolumn{2}{c}{ Keadaan } \\
\cline { 3 - 3 } & & Ada \\
\hline 1 & Laporan Realisasi Penyerapan Dana Bidikmisi & $\checkmark$ \\
\hline 2 & Laporan Penetapan Penerima Bidikmisi melalui SIM Bidikmisi & $\checkmark$ \\
\hline
\end{tabular}




\begin{tabular}{clc}
\hline 3 & $\begin{array}{l}\text { Laporan Perkembangan Indek Prestasi (IP) Penerima Bidikmisi } \\
\text { melalui SIM Bidikmisi }\end{array}$ & $\checkmark$ \\
\hline 4 & Laporan Pengganti Penerima Bidikmisi & $\checkmark$ \\
\hline 5 & Kegiatan Sosialisasi Program Bidikmisi & $\checkmark$ \\
\hline 6 & Kegiatan Pelatihan Kemahasiswaan Peserta Bidikmisi & $\checkmark$ \\
\hline 7 & Kegiatan Pendidikan Mahasiswa Peserta Bidikmisi & $\checkmark$ \\
\hline
\end{tabular}

Sumber: Wawancara, Dokumentasi dan Observasi

\section{Daya Dukung SDM}

Tabel 11 Sumber Daya Manusia Penanggung Jawab dan Pelaksana Program

\begin{tabular}{|c|c|c|c|c|c|}
\hline \multirow{3}{*}{ No } & & \multirow{3}{*}{ Unsur Pengelola } & \multicolumn{2}{|c|}{ Kondisi Obyektif } & \multirow{3}{*}{ Ket } \\
\hline & & & & & \\
\hline & & & Ada & $\begin{array}{l}\text { Tidak } \\
\text { Ada }\end{array}$ & \\
\hline 1 & $\begin{array}{l}\text { Penanggung } \\
\text { Jawab }\end{array}$ & Rektor & $\sqrt{ }$ & & \\
\hline 2 & Pelaksana & Wakil Rektor Bidang Akademik & $\sqrt{ }$ & & \\
\hline 3 & & Wakil Rektor Bidang Kemahasiswaan & $\checkmark$ & & \\
\hline 4 & & Kepala Biro Bidang Akademik & $\checkmark$ & & \\
\hline 5 & & Kepala Biro Bidang Kemahasiswaan & $\checkmark$ & & \\
\hline 6 & & Kepala Biro Bidang Keuangan & $\checkmark$ & & \\
\hline 7 & & $\begin{array}{l}\text { Kepala Biro Lembaga Pengkajian dan } \\
\text { Pengembagan Tahid (LP2T) }\end{array}$ & $\checkmark$ & & \\
\hline 8 & & Kepala Biro IT & & & $\begin{array}{l}\text { Pada desain } \\
\text { program tidak } \\
\text { terdapat unsur } \\
\text { pelaksana } \\
\text { kepala biro IT }\end{array}$ \\
\hline
\end{tabular}

Sumber: Wawancara, Dokumentasi dan Observasi

Berdasarkan tabel 11 terdapat tujuh unsur yang memenuhi pada aspek SDM pelaksana program. Dengan demikian, semua SDM pelaksana program beasiswa Bidikmisi terpenuhi. Unsur kepala biro IT pada saat pelaksanaan program menjadi salah satu team dalam unsur pengelola, namun tidak tertulis pada desain program.

Dosen merupakan unsur lain yang menjadi factor pendukung pelaksanaan program beasiswa Bidikmisi. Secara administrative jumlah dosen pada program studi yang menjadi pelaksana proses pembelajaran untuk mahasiswa peserta beasiswa Bidikmisi memadai. Hal tersebut telihat dari nisbah dosen dan mahasiswa yang sesuai dengan aturan perundang-udangan yang berlaku.

Dosen-dosen di UNIDA memiliki kualifikasi akademik yang mumpuni dan sesuai dengan bidang keahlian masing-masing. Mahasiswa diberikan dosen yang professional karena dosen UNIDA adalah dosen-dosen yang memiliki prestasi yang baik. Hal itu dibuktikan dengan banyaknya dosen yang mengikuti hibah DIKTI dan diraihnya kluster utama dalam bidang penelitian oleh UNIDA. Dosen selalu melibatkan mahasiswa Bidikmisi dalam penelitiannya. Ini yang menjadikan atmosfir riset UNIDA menjadi baik (A2.4). 
Tabel 12 Kondisi Obyektif Dosen pada Program Studi Mahasiswa Peserta Program

\begin{tabular}{|c|c|c|c|}
\hline \multirow[b]{2}{*}{ No } & \multirow[b]{2}{*}{ Program Studi } & \multicolumn{2}{|c|}{ Ketersediaan Dosen } \\
\hline & & Memadai & Tidak Memadai \\
\hline 1 & Agrobisnis & $\checkmark$ & \\
\hline 2 & Agroteknologi & $\checkmark$ & \\
\hline 3 & Perikanan & $\checkmark$ & \\
\hline 4 & Peternakan & $\checkmark$ & \\
\hline 5 & Teknologi Pangan dan Gizi & $\checkmark$ & \\
\hline 6 & Teknologi Industri Pertanian & $\checkmark$ & \\
\hline 7 & Akuntansi & $\checkmark$ & \\
\hline 8 & Manajemen & $\checkmark$ & \\
\hline 9 & Ilmu Hukum & $\checkmark$ & \\
\hline 10 & Administrasi Publik & $\checkmark$ & \\
\hline 11 & Ilmu Komunikasi & $\checkmark$ & \\
\hline 12 & Pendidikan Guru Sekolah Dasar & $\checkmark$ & \\
\hline
\end{tabular}

Sumber: Wawancara, Observasi dan Dokumentasi

\section{Daya Dukung Sarana Prasarana}

Hasil penelitian tentang realisasi sarana prasarana di dapatkan hasil bahwa UNIDA memiliki 4 gedung dengan rincian Gedung A terdiri dari rektorat dan ruang pasca sarjana, Gedung B terdiri dari ruang perkuliahan Fakultas Keguruan dan Ilmu Pendidikan, Fakultas Hukum, Fakultas Pangan Halal, Fakultas Pertanian dan Fakultas Ekonomi Islam. Sementara Gedung $\mathrm{C}$ terdiri dari ruang perpustakaan dan ruang auditorium. Gedung D terdiri dari ruang Fakultas Ekonomi, Fakultas Ilmu Sosial dan Politik serta Fakultas. UNIDA memiliki 3 asrama yang terdiri dari 1 asrama mahasiswa untuk perempuan, 1 asrama mahasiswa untuk laki-laki dan 1 asrama untuk dosen dan pegawai.

UNIDA memiliki sarana prasarana yang memadai untuk melakukan proses perkuliahan mahasiswa. Kami memiliki 5 gedung untuk memfasilitas mahasiswa melakukan kegiatan kurikulernya. Ada Gedung A, Gedung B, Gedung C, Gedung D dan Gedung E.

Tabel 13 Kondisi Obyektif Sarana Prasarana Pelaksanaan Program

\begin{tabular}{|c|c|c|c|}
\hline \multirow[t]{2}{*}{ No } & \multirow[t]{2}{*}{ Kondisi Obyektif Sarana Prasarana } & \multicolumn{2}{|c|}{ Ketersediaan } \\
\hline & & Ada & Tidak Ada \\
\hline 1 & Gedung Kampus & $\checkmark$ & \\
\hline 2 & Ruang Perkuliahan Sesuai Program Studi & $\checkmark$ & \\
\hline 3 & Mebeler Ruang Perkuliahan & $\checkmark$ & \\
\hline 4 & Penerangan Ruang Perkuliahan & $\checkmark$ & \\
\hline 5 & Peralatan Belajar & $\checkmark$ & \\
\hline 6 & Ruang Perpustakaan & $\checkmark$ & \\
\hline 7 & Sumber Belajar & $\checkmark$ & \\
\hline 9 & Laboratorium Bahasa & $\checkmark$ & \\
\hline 10 & Laboratorium Peternakan & $\checkmark$ & \\
\hline 11 & Laboratorium Pertanian & $\checkmark$ & \\
\hline 12 & Laboratorium Hukum & $\checkmark$ & \\
\hline 13 & Laboratorium Perbankan & $\checkmark$ & \\
\hline 14 & Laboratorium Sains & $\checkmark$ & \\
\hline
\end{tabular}




\begin{tabular}{|c|c|c|c|}
\hline \multirow[t]{2}{*}{ No } & \multirow[t]{2}{*}{ Kondisi Obyektif Sarana Prasarana } & \multicolumn{2}{|c|}{ Ketersediaan } \\
\hline & & Ada & Tidak Ada \\
\hline 15 & Ruang Micro Teaching & $\checkmark$ & \\
\hline 16 & Lapangan Olahraga & $\checkmark$ & \\
\hline 17 & Sarana Ibadah (masjid/mushala) & $\checkmark$ & \\
\hline 18 & Toilet & $\checkmark$ & \\
\hline 19 & Asrama Mahasiswa & $\checkmark$ & \\
\hline 20 & Ruang Unit Kerja Mahasiswa (UKM) & $\checkmark$ & \\
\hline 21 & Ruang Sekretariat BEM UNIDA & $\checkmark$ & \\
\hline 22 & Ruang Sekretariat BEM Fakultas & $\checkmark$ & \\
\hline 23 & Ruang HIMMA per Program Studi & $\checkmark$ & \\
\hline 24 & Ruang Dosen & $\checkmark$ & \\
\hline 25 & Ruang Struktural & $\checkmark$ & \\
\hline 26 & Parkir & $\checkmark$ & \\
\hline 27 & Dapur & $\checkmark$ & \\
\hline
\end{tabular}

Sumber: Wawancara, Observasi dan Dokumentasi

\section{Tugas dan Tanggung Jawab Pengelola program}

Tugas dan tanggung jawab UNIDA selaku pengelola program beasiswa Bidikmisi diantaranya adalah mendistribusikan kuota, melakukan diseminasi informasi, verifikasi, dan menyusun laporan pengelolaan Bidikmisi.

Mahasiswa Bidikmisi menjadi tanggung jawab seluruh insan UNIDA. Namun berada langsung dibawah jalur 3 karena tentang kemahasiswaan. Sehingga yang melalukan pembinaan dan pengelolaan Bidikmisi adalah SDM yang ada pada jalur 3 dan jalur 1 karena harus memantau nilai IP dan IPK nya (A1.7).

Tabel 14 Realisasi Tugas dan Tanggung Jawab Pengelola Program

\begin{tabular}{|c|c|c|c|}
\hline \multirow[t]{2}{*}{ No } & \multirow[t]{2}{*}{ Jenis Tugas dan Tanggung Jawab } & \multicolumn{2}{|c|}{ Realisasi } \\
\hline & & $\mathrm{Ya}$ & Tidak \\
\hline 1 & Mendistribusikan kuota Bidikmisi untuk mahasiswa baru & $\checkmark$ & \\
\hline 2 & Melakukan diseminasi informasi & $\checkmark$ & \\
\hline 3 & Melakukan verifikasi calon mahasiswa penerima Bidikmisi PTS & $\checkmark$ & \\
\hline 4 & Menetapkan dengan Surat Keputusan penerima Bidikmisi & $\checkmark$ & \\
\hline 5 & Menyalurkan dana Pengelolaan Bidikmisi & $\checkmark$ & \\
\hline 6 & Monitoring dan Evaluasi & $\checkmark$ & \\
\hline 7 & Merekomendasikan penggantian penerima Bidikmisi & $\checkmark$ & \\
\hline 8 & Membantu UNIDA melaporkan IPK melalui sistem daring & $\checkmark$ & \\
\hline 9 & Penyusunan laporan pelaksanaan dan dana pengelolaan Bidikmisi & $\checkmark$ & \\
\hline
\end{tabular}

Sumber: Wawancara, dan Dokumentasi Biro Kemahasiswaan dan PMB

Tabel 15 Pencapaian dan Kesenjangan serta Analisis Penyebab/Alternatif Pemecahan Masalah Pelaksanaan Program Beasiswa Bidikmisi di Universitas Djuanda Bogor

\begin{tabular}{cllll}
\hline No & Indikator & \multicolumn{2}{c}{$\begin{array}{c}\text { Pencapaian dan } \\
\text { Kesenjangan }\end{array}$} & \multicolumn{2}{c}{ Analisis Penyebab/ } \\
& & Alternatif Pemecahan Masalah \\
\hline 1 & $\begin{array}{l}\text { Terdapat unsur penanggung } \\
\text { jawab dan pelaksana pengelola } \\
\text { program }\end{array}$ & $\begin{array}{l}\text { Aspek } \\
\text { pengelola struktur }\end{array}$ & $\begin{array}{l}\text { Senantiasa memiliki struktur } \\
\text { beasiswa Bidikmisi } \\
\text { pengelola program yang terdiri } \\
\text { sesuai kriteria }\end{array}$ & $\begin{array}{l}\text { dari penanggung jawab dan } \\
\text { pelaksana program }\end{array}$ \\
\hline
\end{tabular}




\begin{tabular}{|c|c|c|c|}
\hline No & Indikator & $\begin{array}{l}\text { Pencapaian dan } \\
\text { Kesenjangan }\end{array}$ & $\begin{array}{c}\text { Analisis Penyebab/ } \\
\text { Alternatif Pemecahan Masalah }\end{array}$ \\
\hline \multirow[t]{4}{*}{2} & $\begin{array}{lcr}\text { Terdapat } & 5 & \text { ketentuan } \\
\text { administrasi dalam } & \text { mekanisme } \\
\text { seleksi, yaitu } & \text { diseminasi } \\
\text { informasi program, persyaratan } \\
\text { administrasi peserta, seleksi } \\
\text { peserta, penetapan calon } \\
\text { penerima program dan tim } \\
\text { seleksi program. }\end{array}$ & 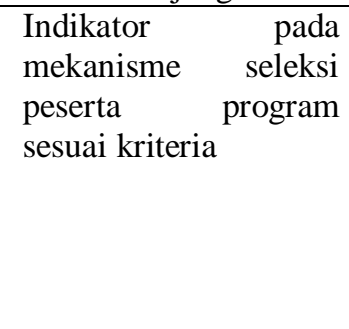 & $\begin{array}{l}\text { Kontinu } r \text { melaksanakan } \\
\text { mekanisme seleksi melalui } \\
\text { diseminasi informasi program, } \\
\text { persyaratan administrasi peserta, } \\
\text { seleksi peserta, penetapan calon } \\
\text { penerima program dan tim adanya } \\
\text { tim seleksi program }\end{array}$ \\
\hline & $\begin{array}{l}\text { Memiliki mekanisme } \\
\text { pembinaan peserta program }\end{array}$ & $\begin{array}{l}\text { Mekanisme pembinaan } \\
\text { peserta program sesuai } \\
\text { kriteria }\end{array}$ & $\begin{array}{l}\text { Kontinu melaksanakan pembinaan } \\
\text { kepada mahasiswa peserta } \\
\text { program beasiswa Bidikmisi }\end{array}$ \\
\hline & $\begin{array}{l}\text { Memiliki mekanisme } \\
\text { monitoring dan supervise yang } \\
\text { sesuai dengan standar }\end{array}$ & $\begin{array}{l}\text { Mekanisme monitoring } \\
\text { dan supervise program } \\
\text { sesuai kriteria. }\end{array}$ & $\begin{array}{l}\text { Kontinu melakukan pencatatan } \\
\text { dan pelaporan pelaksanaan } \\
\text { program beasiswa bidikmisi }\end{array}$ \\
\hline & $\begin{array}{l}\text { Memiliki mekanisme } \\
\text { pelaporan program }\end{array}$ & $\begin{array}{l}\text { Mekanisme } \\
\text { pelaksanaan program } \\
\text { sesuai kriteria }\end{array}$ & \begin{tabular}{lrr} 
Kontinu & \multicolumn{2}{c}{ melaksanakan } \\
mekanisme pelaporan & sesuai \\
dengan pedoman program & \\
\end{tabular} \\
\hline 3 & $\begin{array}{l}\text { Memiliki sumber daya } \\
\text { manusia pelaksana program } \\
\text { sebagai penanggung jawab } \\
\text { dan pelaksana program serta } \\
\text { memiliki dosen pada program } \\
\text { studi peserta program yang } \\
\text { memadai }\end{array}$ & $\begin{array}{l}\text { Sumber daya manusia } \\
\text { pelaksana program } \\
\text { sesuai kriteria }\end{array}$ & $\begin{array}{l}\text { Kontinu dalam menyediakan } \\
\text { sumber daya manusia sebagai } \\
\text { penanggung jawab dan pelaksana } \\
\text { program serta menyiapkan dosen } \\
\text { pada setiap program studi sesuai } \\
\text { pedoman program }\end{array}$ \\
\hline 4 & $\begin{array}{l}\text { Memiliki sarana prasarana } \\
\text { sebagai penunjang } \\
\text { pembelajaran bagi } \\
\text { program }\end{array}$ & $\begin{array}{l}\text { Sarana prasarana } \\
\text { sesuai kriteria }\end{array}$ & 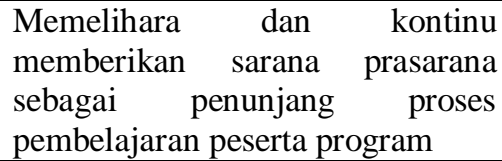 \\
\hline 5 & $\begin{array}{l}\text { Memiliki tugas dan tanggung } \\
\text { jawab pengelola yang } \\
\text { terealisasi }\end{array}$ & $\begin{array}{lr}\text { Tugas dan tanggung } \\
\text { jawab } & \text { pengelola } \\
\text { program sesuai kriteria }\end{array}$ & $\begin{array}{l}\text { Kontinu melaksanakan tugas dan } \\
\text { tanggung jawab pengelola } \\
\text { program }\end{array}$ \\
\hline
\end{tabular}

\section{PEMBAHASAN}

Pentingnya aspek implementasi dari perencanaan program dikemukakan oleh Karen yang menyatakan bahwa:

Program implementation is where it all comes together and the program is put into action. Often, however, impelementation does not go as planned. Most programs face implementation challenges, and the ability of project planners to respond effectively to these challenges often marks the difference between a successful program and one that fails to achieve its goals (Karen Matison Hess dan Cristine Hess Orthmann, 2012).

Implementasi program adalah dimana semuanya datang bersamaan dan program diletakan pada tindakan. Seringkali implementasi tidak sebaik apa yang direncanakan. Kebanyakan program menghadapi tantangan dalam implementasinya dan kemampuan dari perencana proyek untuk menjawab secara efektif kepada tantangan-tantangan tersebut. Hess dan Orthmann menyatakan bahwa "program 
execution is where it all comes together and the program is put into action. Often, however, impelementation does not go as planned" (Karen Matison Hess dan Cristine Hess Orthmann, 2012). Implementasi suatu program sebenarnya adalah proses yang membutuhkan upaya besar untuk mencapai atau meninjaunya dengan lebih baik. The implementation needs improvement efforts cosisting of $: a)$ depth of change, $b$ ) sustainability, c) spread, and d) ship in reform (Rubin et al., 2017).

Struktur pengelola program beasiswa Bidikmisi UNIDA melibatkan sejumlah sumber daya manusia, mulai dari rektor, wakil rektor, dan kepala biro menjadi bagian dalam pengelolaan program dengan tugas dan tanggung jawab pengelola program masing-masing. Semua pengelola program beasiswa Bidikmisi di UNIDA berjalan sesuai dengan tugas dan fungsinya masing-masing.

\section{Daya Dukung Administrasi}

Sistem administrasi program beasiswa Bidikmisi mencakup 4 indikator, yaitu mekanisme seleksi peserta, pembinaan peserta, monitoring dan evaluasi serta pelaporan pelaksanaan program.

\section{Mekanisme Seleksi Peserta Program}

Mekanisme seleksi peserta program adalah proses yang dilakukan sejak pengumuman penerimaan calon peserta sampai dengan pengumuman penetapan yang diterima program. Terdapat 5 ketentuan administrasi dalam mekanisme seleksi, yakni diseminasi informasi program, persyaratan administrasi peserta, seleksi peserta, penetapan calon penerima program dan tim seleksi program dengan 32 indikator.

Mekanisme seleksi peserta program beasiswa Bidikmisi di UNIDA Bogor terdiri dari:

Diseminasi informasi, mencakup pengumuman penerimaan program melalui berbagai media masa, dan jadwal kegiatan penerimaan.

Persyaratan program, mencakup syarat administrasi peserta yang harus di lampirkan pada saat pendaftaran yang terdiri dari: formulir pendaftaran, raport, piagam prestasi, kartu keluarga, surat keterangan tidak mampu, kartu tanda siswa, photo rumah, photo bersama keluarga, photo pribadi, surat rekomendasi dari sekolah, photo copy rekening listrik dan surat penghasilan orang tua.

Seleksi peserta program, mencakup TPA, Bahasa Inggris, Wawancara, dan Psikotest. Penetapan calon penerima Bidikmisi yang terdiri dari SK rector tentang penetapan penerima beasiswa dan dokumen sosialisasi peserta yang diterima. Tim seleksi peserta program yang terdiri dari panitia pengelola program.

Analisis terhadap SDM difokuskan untuk mengetahui tersedia atau tidaknya sumberdaya pengelola program dan dosen pada perguruan tinggi sesuai desain program. Ketersediaan SDM ini menjadi penting karena akan menjadi jantungnya implementasi program. Melalui SDM yang handal, maka akan tercipta lulusan dan outcome Bidikmisi sesuai tujuan program. Pimpinan satuan pendidikan bertugas dan bertanggung jawab mengelola satuan pendidikan pada pendidikan formal atau nonformal (Aliyyah, 2018). Higher education administrators, who are invested in community-engaged partnerships and in research more broadly, should consider the broader implications and commitments involved in these collaborative efforts (Núñez, 2014). Human resources who will be ready to compete at the international level. 
Thus, Indonesia will have many multi-talented teachers who have an impact on the many achievements of students and graduates as a form of a sound education system (Aliyyah et 11. 2020), (Aliyyah, Rasmitadila, Megan. 2020).

Sarana prasarana pendidikan menjadi faktor pendukung berjalan baiknya program beasiswa Bidikmisi karena akan membantu mahasiswa peserta program dalam menjalankan tugas pembelajaran di bangku perguruan tinggi. Earthman, Mc Koy et all mengemukakan "a god condition of school building and components support the enhancement in teaching and learning progress in the school (Nuraihan Mohd Ibrahim et al., 2016). Sarana prasarana kampus yang baik akan meningkatkan kemajuan proses pembelajaran.

Tugas dan tanggung jawab pengelola program merupakan kegiatan mendistribusikan kuota untuk mahasiswa baru, melakukan diseminasi informasi, melakukan verifikasi calon mahasiswa penerima Bidikmisi PTS, menetapkan dengan SK penerima Bidikmisi, menyalurkan dana, monitoring dan evaluasi, merekomendasikan penggantian penerima Bidikmisi, membantu UNIDA melaporkan IPK melalui system daring dan penyusunan laporan pelaksanaan dana.

Baiknya realisasi tugas dan tanggung jawab pengelola program menjadikan anggaram BM tersalurkan dengan benar sesuai dengan konsep beasiswa yang diperuntukan bagi mahasiswa miskin yang berprestasi. "Bidikmisi "(BM) is an extraordinary scholarship provided by the Government of Indonesia with two criteria main: economic needs and academic performance (Aliyyah, Rosyidi, \& Rugaiyah, 2019). The scholarship program for students is not economically capable but achievers namely BidikMisi (BM), provides an opportunity for educational expansion for social, economic equality in low-achieving middle-class society in Indonesia (Aliyyah, Rosyidi, \& Yazid, 2019).

\section{SIMPULAN}

Pelaksanaan program beasiswa Bidikmisi pada UNIDA telah sesuai dengan perencanaan kriteria program. Struktur pengelola program berperan sesuai dengan tugas dan fungsinya. Daya dukung administrasi yang terdiri dari mekanisme seleksi peserta program, pembinaan peserta program, monitoring dan evaluasi serta pelaporan pelaksanaan program berjalan dengan sangat baik. SDM pada UNIDA sangat mendukung program beasiswa Bidikmisi sehingga tugas dan tanggung jawab pengelola program terealisasi dengan sangat baik.

\section{DAFTAR PUSTAKA}

Aliyyah, R. R. (2018). Pengelolaan Pendidik dan Tenaga Kependidikan. Jakarta: Polimedia Publishing

Aliyyah, R. R., Rosyidi, U., \& Rugaiyah. (2019). Higher Education Scholarship: Gate to Develop Educational Human Resource Quality. International Journal for Educational and Vocational Studies, 1(4)

Aliyyah, R. R., Rosyidi, U., \& Yazid, R. (2019). An Evaluative Study of an Education Scholarship Program (Bidikmisi) for Students in Indonesia. Journal of Physics: Conference Series, 1175, 1-7. https://doi.org/10.1088/17426596/1175/1/012171 
Aliyyah, R. R . (2020). Outstanding Teacher Model Assistance: Effective Steps to be Competitive Human Resources. International Journal of Advanced Science and Technology 29(7), 3255-3262

Aliyyah, R. R., Rasmitadila, R. R., \& Megan, M. (2020). Are the Assessment Criteria and the Role of Educational Stakeholders Able to Make Outstanding Teacher. International Journal of Psychosocial Rehabilitation, 24(06)

Benavot, A. (2016a). Assuring Quality Education and Learning: Lessons from Education for All. PROSPECTS. https://doi.org/10.1007/s11125-016-9386-1

Direktorat Jenderal Pembelajaran dan Kemahasiswaan Kementerian Riset Teknologi dan Pendidikan Tinggi. (2017). Pedoman Bantuan Biaya Pendidikan Bidikmisi Tahun 2017.

Karen, M. H., \& Cristine, H. O. (2012). Management dan Supervision in Law Enforcement. Clifton Park, USA: Delmar

Kementerian Pendidikan dan Kebudayaan. (2014). Laporan Pelaksanaan Program Bidikmisi Semester Genap Tahun Akademik 2013/2014. Jakarta: Kemendikbud

Kemristek Dikti. (2016b). Laporan Program Beasiswa Bidikmisi Subdit Kesejahteraan dan Kewirausahaan Belmawa Kemenristekdikti. Jakarta: Kemristek Dikti

Núñez, G. G. (2014). Engaging Scholarship with Communities. Journal of Hispanic Higher Education, 13(2), 92-115. https://doi.org/10.1177/1538192713515911

Nuraihan, M. H. (2016). Assessment on the Condition of School Facilities: Case Study of The Selected Public Schools in Gombak District. Procedia-Social and Behavioral Sciences

Ozturk, A. D. (2017). Developing Attitudes Towards Human Rights Through Socioscientific Issuesin Science Courses: An Action Research. RemieMultidisciplinary J. Educ. Res, 6(3)

Rubin, M., Patrick, S. K., Goldring, E. B., Rubin, M., Patrick, S. K., Goldring, E. B., \& Goldring, E. B. (2017). Dilemmas of Prescriptive Practices and Perceived Alignment in Program Implementation Dilemmas of Prescriptive Practices and Perceived Alignment in Program Implementation. Peabody Journal of Education, 92(5), 609-626. https://doi.org/10.1080/0161956X.2017.1368646

Undang Undang Dasar Negara Republik Indonesia Tahun 1945. (1945). Jakarta: UUD 1945 